\title{
Post-salt trapping mechanism of south-east Pre-Caspian and its application to petroleum exploration
}

\author{
Aitbek Akhmetzhanov ${ }^{1} \cdot$ Geroy Zholtayev ${ }^{2} \cdot$ Abdelkader Djeddou $^{3} \cdot$ Gauhar Akhmetzhanova $^{4} \cdot$ Bauyrzhan Oraz $^{4}$
}

Received: 25 April 2020 / Accepted: 30 July 2020 / Published online: 9 August 2020

(c) The Author(s) 2020

\begin{abstract}
The Kungurian saliferous sediments of the Pre-Caspian sedimentary basin represented by thick stratum of rock salt with interlayered lenses of anhydrites, terrigenous and carbonate rocks. Initial thickness of these sediments estimated as 4000-4500 m at the center of the depression and 1000-2000 $\mathrm{m}$ on the edges of the basin. The processes of halokinesis led to formation of more than 1200 salt dome structures represented by salt diapirs and walls, ridges and salt pillows. Number of salt dome related structures of Mesozoic clastic deposits revealed by seismic exploration carried out in 70-90's of last century are quite common on the south-eastern part of the Pre-Caspian Sedimentary basin. Most of hydrocarbon pools in post-salt clastic rocks have been discovered on fault-related anticline prospects which are derived from salt tectonics morphologically variable (Munyithya et al. Petrol Explor Prod Technol 10: 2257-2267. https://doi.org/10.1007/s13202-020-00917-1, 2020). Other potential traps anticipated in the area are stratigraphic traps, pinch-out and unconformity-related traps, trapped by salt domes and walls or by salt overhang, etc.
\end{abstract}

Keywords Seal $\cdot$ Pre-Caspian depression $\cdot$ Stratigraphic units $\cdot$ Structural interpretation $\cdot$ Trapping mechanism $\cdot$ Salt diapirs

\section{Introduction}

Pre-Caspian sedimentary basin, covering area of more than $500,000 \mathrm{~km}^{2}$ (Fig. 1), is one of prolific oil and gas provinces with unique geological structure, and despite more than a century of exploration and production history is still remains poorly understood. The evolution of the Pre-Caspian has

Aitbek Akhmetzhanov

a.akhmetzhanov@kbtu.kz

Geroy Zholtayev

ignkis@mail.ru

Abdelkader Djeddou

abdelkader.djeddou@cgg.com

Gauhar Akhmetzhanova

gauhar.akhm@gmail.com

Bauyrzhan Oraz

urbana12@mail.ru

1 Kazakh-British Technical University, Almaty, Kazakhstan

2 Institute of Geological Sciences Named After K.I. Satbaev, Almaty, Kazakhstan

3 Compagnie Générale de Géophysique, Massy, France

4 Satbayev University, Almaty, Kazakhstan identified a wide stratigraphic range for oil and gas accumulation. By now commercial accumulations of hydrocarbon set in the interval from the Middle Devonian to the Pliocene. Major oil and gas potential associated with subsalt sediments which are still underexplored by modern seismic and drilling data. Most of discoveries in this complex made in near-edge zones of the depression within the Astrakhan-Aktyubinsk system of highs and largest oil and gas reserves discovered within carbonate reservoirs (KMG Annual Report 2017; Abilkhasimov 2016; Ulmishek 2001; Soloviev 1992). Prospects for oil discovery also high enough in the post-salt complex of sediments, which has complex geological settings due to active salt diapirism (Quirk and Pilcher 2005; Osinowo et al. 2018).

Structural interpretation of newly acquired 2D/3D seismic data and historical data sets allowed to identify potentially oil-bearing traps within post-salt succession of the area under the study. Existing structure maps were modified using modern interpretation software (Kirilov and Zakrevsky 2014) with the aim to acquire additional geological information. Review of published earlier literature and reports, data from neighboring oil fields, nearby exploration areas and extensive analysis of geological-geophysical data allowed better understanding of new opportunities, leads and 


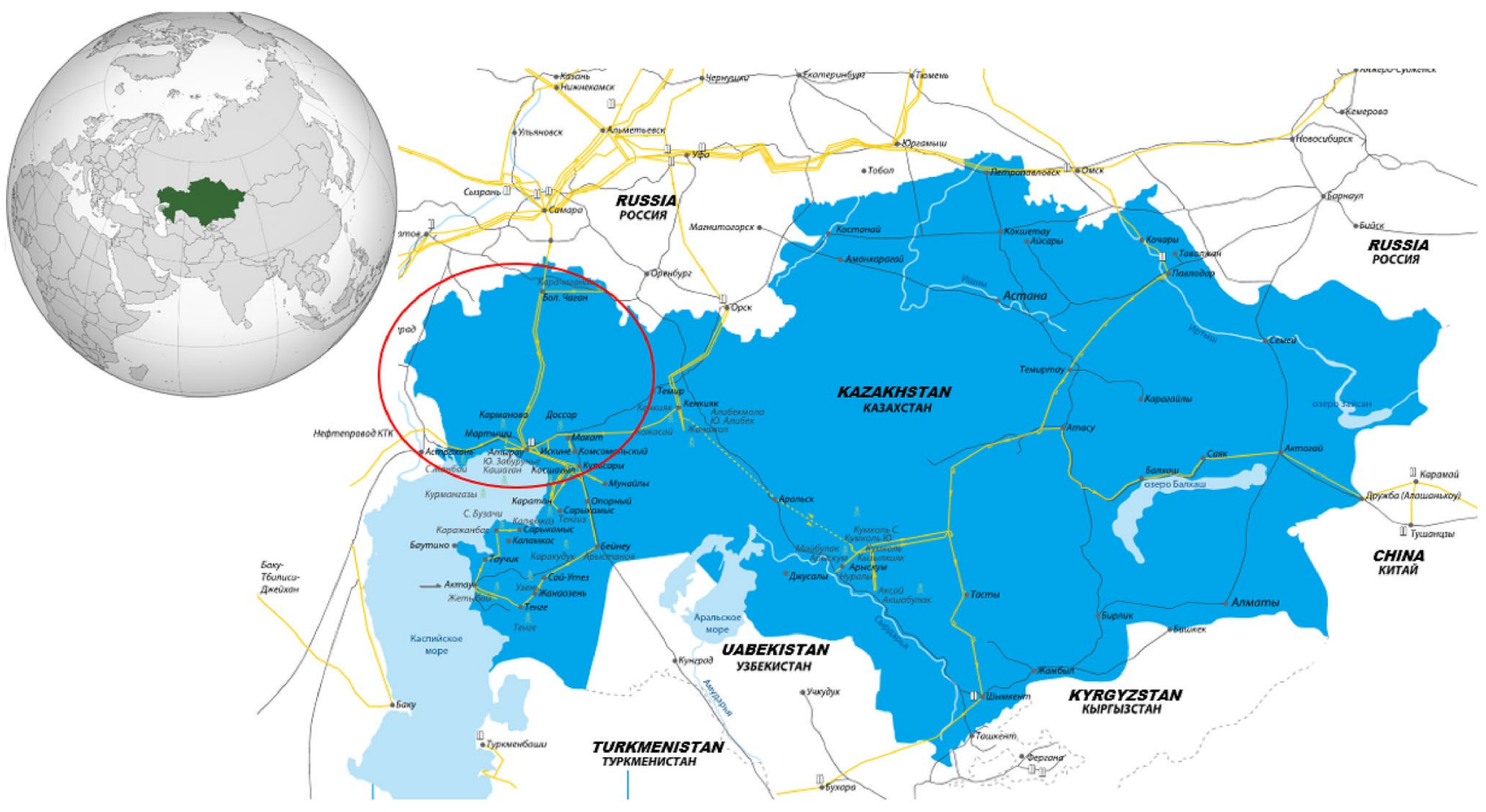

Fig. 1 Location map of the Pre-Caspian Sedimentary Basin, West Kazakhstan and neighboring CIS countries (modified from KMG Annual Report 2017)

prospects and to identify additionally different trap types within studied geological succession.

\section{Geological settings}

Specificity of the geodynamic development of the Pre-Caspian depression, which caused the emergence of AstrakhanAktyubinsk island-arc system and the subsequent formation of deep-water basin, predetermined the wide development of large tectonic and sedimentological structures in the sedimentary cover of the Pre-Caspian. According to Zholtaev and Talaev (1974), Dalyan and Bulekbayev (1993), Brunet et al. (1999), Volozh et al. (2003), Astrakhan-Aktyubinsk system of basement highs predetermined formation of arched uplifts, and ablation of clastic deposits from the crumbling folded structures (Fig. 2). Platform highs and intrabasin structures has led to the formation of local and regional pinchout zones. The basement highs in the subsalt sediments correspond to the elevated zones, which reflected on the subsalt horizons (Davies Okere and Steve Toothill 2012; Klett et al. 2010; Katherine and Mark 2012).

Sedimentary succession the Pre-Caspian basin represented by three structural complexes, which differ in value and ratio of velocity-density, lithological composition and degree of deposits dislocation (Fig. 3). They are:

- The Lower pre-Kungurian or subsalt complex;
- The Middle saliferous complex which consists of hydrochemical sediments of Kungurian stage of the Lower Permian and variegated sediments of the Upper Permian;

- The Mesozoic cover combining Triassic, Jurassic, Cretaceous and Cenozoic sediments.

The formation, reactivation and emplacement of salt during post-Kungurian time have been modeled by several authors during last decades. Yu. Volozh et al. (2003) summarized salt structure and its evolution history within the basin. The rock salt deposited in the area during Kungurian and Kazanian age and initiated to be deformed to build inclined walls and salt pillows during Tatarian age of Late Permian, equidimensional and wall-like pillows, rollers, anticlines, and turtlebacks of Kungurian salt, walls and domes where halokinesis involved both Kungurian and Kazanian salt or halokinesis involved only Kungurian salt, diapiric by the end of the Permian, end of the Triassic and end of the Jurassic, not diapiric yet, but some have surfaced and extruded or been recycled.

During Triassic period, the rock salt activated severely due to thickening overburden to turn over salt diapirs, turtleback structures and salt stocks.

Upper Permian and Lower Mesozoic stratigraphic units have been broken and disturbed by salt tectonics and they were intensively dislocated in some areas. In the Late Mesozoic period there was a moderate redistribution of salt, which resulted in uplift of Mesozoic deposits on the top of salt. 


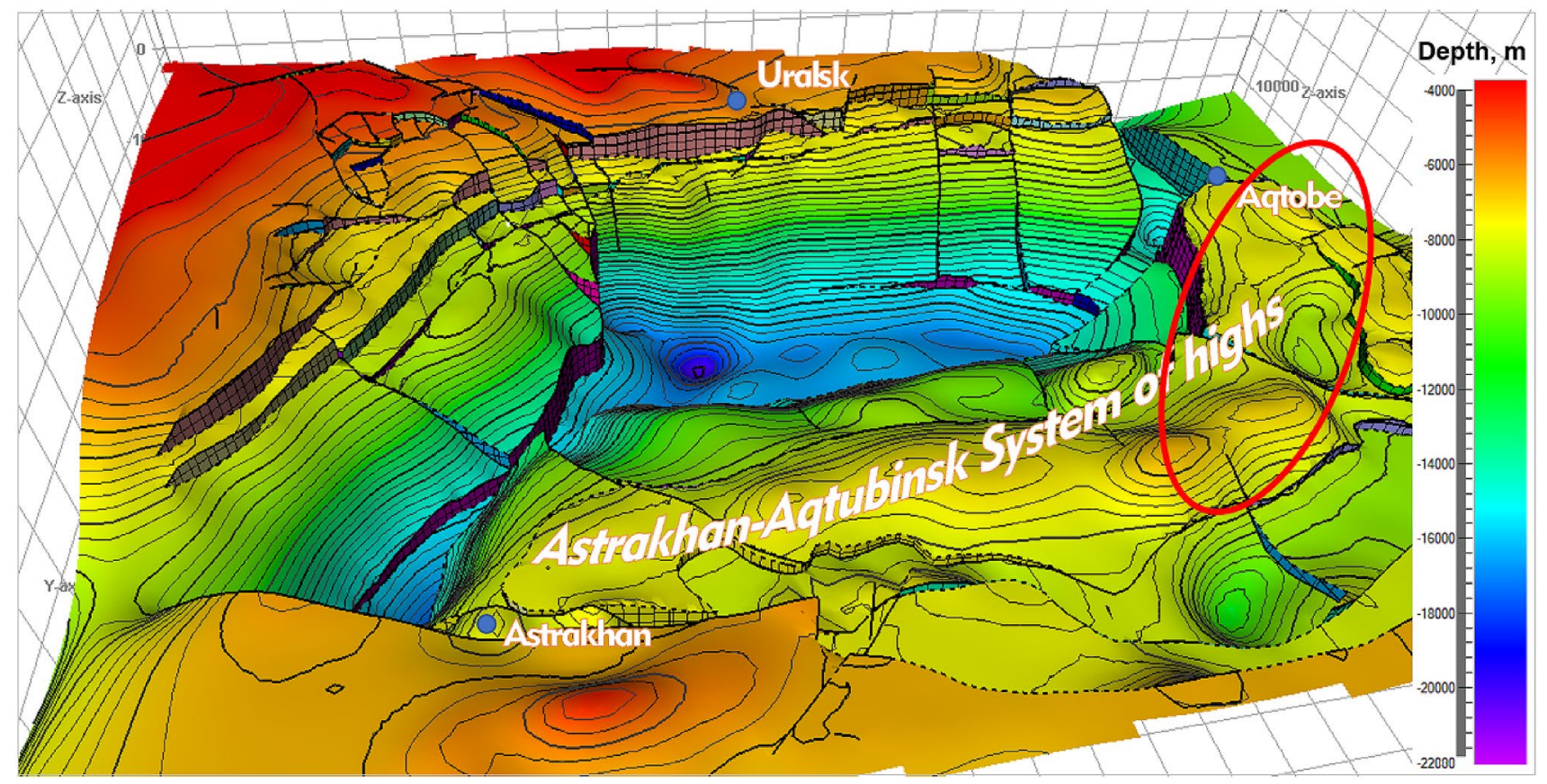

Fig. 2 Basement structural map of the Pre-Caspian sedimentary Basin (modified from Soloviev 1992; Ulmishek 2001; Volozh et al. 2003). The red circle showing area under the study

Finally, in the period from Cretaceous to Pliocene, the salt reactivated and emplaced to current position. There is a major angular unconformity between the Upper Permian and Mesozoic deposits. The Lower Triassic lies on the Kungurian and/or various deposits of the Upper Permian. On the top of salt, the Lower Triassic deposits are elevated and eroded out partially or completely while the Jurassic unit lies unconformably on the Kungurian and Lower Triassic sequences.

The subsurface geology of the area studied by number of wells during previous exploration works. Drilling results provided wide-range data for further analysis. Subsalt section within area revealed by 19 deep wells throughout the entire area under the study and post-salt section drilled by shallow wells allowed to refine lithological settings of territory. The well East Akzhar-5, drilled to 5843 m, penetrated Devonian to Quaternary sediments. Stratigraphy identification carried out using wireline logging records and core description. Such wise the description of regional geology and lithology based on data obtained from those wells and seismic data, available to date.

\section{Stratigraphy and sedimentology}

Stratigraphic and structural interpretation carried out mainly by lithological description of cores and cuttings samples from wells and the result of microfauna and palynological analyses, tied with well data when applicable (Zholtaev et al. 2019).

Paleozoic deposits of the area distinguished within the Kungurian stage of the Lower and Upper Permian. The Kungurian deposits consist of halogenic and upper terrigenoussulphate stratum. The halogenic stratum is composed of the rock salt with thin layers of gypsums, anhydrites, potassium salts, and rare terrigenous clastic rocks.

The Upper Permian section (P2) composed of argillitelike, brick-red, calcareous, micaceous, sandy, irregularly stratified, dense clays with inclusions of pyrite crystals, and with intercalation of medium-grained, greenish-brown sand and brownish-grey, polymictic, fine-grained, calcareous sandstone. Ufimian, Kazanian and Tatarian deposits distinguished in the thick stratum of the Upper Permian.

Mesozoic deposits represented by the Triassic, Jurassic and Cretaceous sequences. Upper and middle Triassic deposits are not recognized within the area or distinguished together with the Lower Jurassic since lithologically similar and there is no analytic criterion available for discrimination of them. The Lower Triassic deposits divided into Vetluga and Baskunchak series. Vetluga series (T1v) of the area is divided into the Sorkol, Kokzhide and Akzhar suites.

The Sorkol suite (T1srk) lies with sharp angular unconformity on the Kungurian and Upper Permian, and lithologically represented by alternation of clays, sands, and sandstones of 3-10 m. thickness. On the top of structures, they have a so-called conglomerate horizon at the bottom

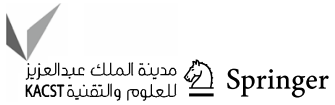




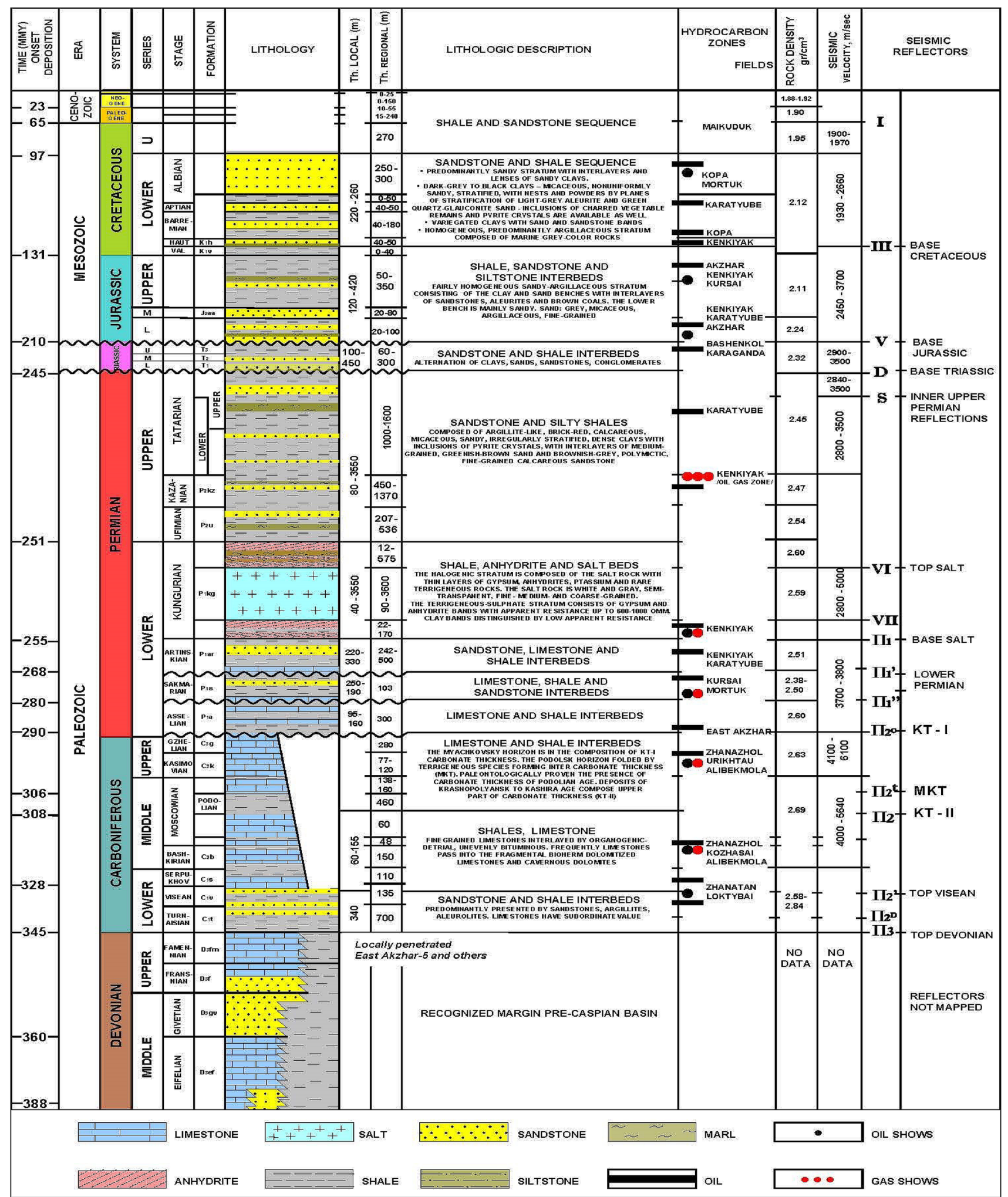

Fig. 3 Generalized stratigraphy column of the eastern boundary of the pre-caspian sedimentary basin (modified from Barde Jean-Pierre et al. 2002) 
of the suite, which are composed of the variegated, clayey, solid, dense pebbles of quartz and silica with the size of 0.5-3 cm (Santamarina et al. 2019a, b).

The Akzhar suite (T1akz) lies concordantly on the lower suite. Lithologically, it is a sandy-clayey suite and it consists of two mainly sandy horizons on the top and at the bottom with the thickness of 20-30 m divided by clay interlayer of 20-30 m thickness.

The Kumsai suite $(\mathrm{T} 1 \mathrm{~km})$ of Baskunchak series is eroded out in the most of area revealed by the wells. Lithologically, this is an argillaceous suite and it is composed of clays with sand and sandstone bands. In the well logs, the suite is distinguished by the generally maximum of SP and GR and the resistivity (apparent resistance) of the suite is about 3-7 ohm·m (Santamarina et al. 2019). The suite is eroded out partly on the top of the structure and even eroded out completely in the most of the wells. The thickness of the suite not subjected to erosion varies from 20 to $62 \mathrm{~m}$ on neighboring areas.

Jurassic system is represented by the homogeneous massive sandy-argillaceous strata of terrestrial carboniferous deposits. The Lower Jurassic section (J1) lies with sharp angular unconformity over the Kungurian and Triassic sequences. Lithologically consists of two formations: the upper formation is mainly composed of clays while the lower formation is mainly sandy and silty sandstones, and distinguished on the basis of palynological (spore-pollen) complexes. Middle Jurassic section (J2) were drilled in the area by number of wells and lithologically represented by fairly homogeneous sandy-argillaceous strata consisting of the clay and sand formation with interlayers of sandstones, aleurites and brown coals. The Upper Jurassic deposits (J1), largely thin, are distinguished according to the microfauna data in a number of wells, but due to their small thickness $(3-10 \mathrm{~m}$.) they are spread sporadically, and it is rather difficult to distinguish them.

The Cretaceous sequence deposited in the area with thickness range from 10 to $20 \mathrm{~m}$ to $300-330 \mathrm{~m}$. The system is represented by only the lower section, the Upper Cretaceous deposits eroded out of the section, and Quaternary sediments lie directly on the Albian stage.

In all parts, the Quaternary deposits cover the original deposits from the surface, they subdivided into two genetic types: alluvial and aeolian.

The Kokzhide (T1kzd) suite lies concordantly on the Sorkol suite. In previous time, this suite was called by a "saw", since it was recognized by high frequency oscillated feature of apparent resistance/resistivity curves in the well logs. The thickness of the T1kzd suite vary from 42 to $113 \mathrm{~m}$., and there is no this suite on the top of some structures, since it was cut off by during Middle Triassic hiatus.

\section{Trap and seal}

The source rock has been proven by presence of producing oil fields in the vicinity of the area of the eastern Pre-Caspian Basin. It is anticipated that Paleozoic shallow marine carbonates and abyssal shale in Devonian, Carboniferous and Lower Permian stage are petroliferous source rocks for hydrocarbons pooled in the region. However, no qualified source rocks have been dedicated by geochemical modeling in the prospect area to date.

The reservoir for post-salt system is composed of a couple of pairs of shallow marine and terrestrial clastics of upper Permian and Triassic age. Sandstones intercalated with siltstones and shale has a good quality of reservoir characteristics $-14-31 \%$ of porosity (Hakiki and Shidqi 2018).

There is a regional impermeable seal of Kungurian salt over the basin for pre-salt play (Kamali et al. 2013; Zhenyun et al. 2015). For post-salt play, low energy clastic sediments of flood plain, slope and abyssal plain act as a seal for small dimension structure. The trapping mechanism is salt related fault-bounded structures in most cases. The generalized petroleum system of the area presented by Barde et al. (2002).

Considerable number of seismic lines acquired and deep wells drilled within entire area under investigation since late 1980 's to early 1990's. Some of those wells also checked hydrocarbon bearing zones within Mesozoic succession.

Seismic acquisition, processing/re-processing and geological-geophysical data interpretation performed in 2006-2009 aimed to identify main reflection horizons and the result of those works was identification of several trap types and structures, such as faulted anticline, salt overhang, stratigraphic, unconformity, etc. (Akhmetzhanov et al. 2017). Most of those related to salt domes characterized by symmetrical or elongated north-west direction features. In the upper part the Kungurian salt occurs at depths of $300 \mathrm{~m}$, and from the depth of approximately $700 \mathrm{~m}$ the salt goes down.

The main interest for the $\mathrm{HC}$ occurrences in a postsalt section is deposits of lower Triassic and upper Permian. The most dynamically expressed horizon, along with the reflecting horizons III and V is the horizon D, which characterizes the deposits of lower Triassic, which is confidently identified in zones between salt domes and, in some cases, with an unconformity overlapped by the bottom of Middle Jurassic deposits. By seismic, Triassic deposits characterized by a series of the high-frequency phases in zones between salt domes with the loss of correlation above salt domes and in the faulting zones. Structures by horizons III, V and D in some cases are pinching

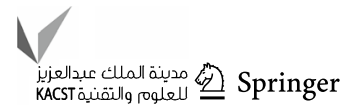


out by slopes of salt domes and the tectonic faults. Upper Permian deposits mainly broken completely by the salt massifs within the studied area. The structure of the area in post Kungurian time is depicted by the structural maps for reflecting horizon D and S, shown on Fig. 4.

In some cases, Permian salt bodies extrude Late Permian formation and dispersed over Late Permian formation by excessive movement of salt, due to Late Permian's fast sedimentation rate. Then the Late Permian formations, dipping to the western direction, trapped by salt walls or stocks and form overhang structures. Overhang trap were proved in several field in the basin (Kotyrtas North, Novobogatinsk fields etc.) and, within area under the study, based on 2D seismic interpretation, several locations defined as overhang-trapped structure (Fig. 5).

Faulted anticline structures around salt dome are the most common traps in post salt sequence. Most of hydrocarbon pools in post-salt clastic rocks have been discovered on fault-related anticlinal prospects which are derived from salt tectonics and morphologically variable (Hanafy et al. 2014, 2017; Herndon 2017) However, the discontinuous character of clastic reservoir rocks and large variability in flows from adjacent wells suggest that hydrodynamic connection between the wells is poor or absent and that many of these pools are actually in fault traps or in stratigraphic traps.

The trapping mechanism in many cases is faulted anticlinal uplifts with a salt core and sealed up-dip by faults (Velaj 2015). The timing of structural faulting is not clear. However, a limited data and analogy with the other field in the basin support that important stage of formation of structures could have been associated with pre-Cretaceous halo-kinematic and orogenic events that are reflected by unconformities.

Other potential of stratigraphic traps is anticipated in the area, which are pinch-out type, unconformity-related type, salt-related type, etc. (Alsouki et al. 2014; Ameloko

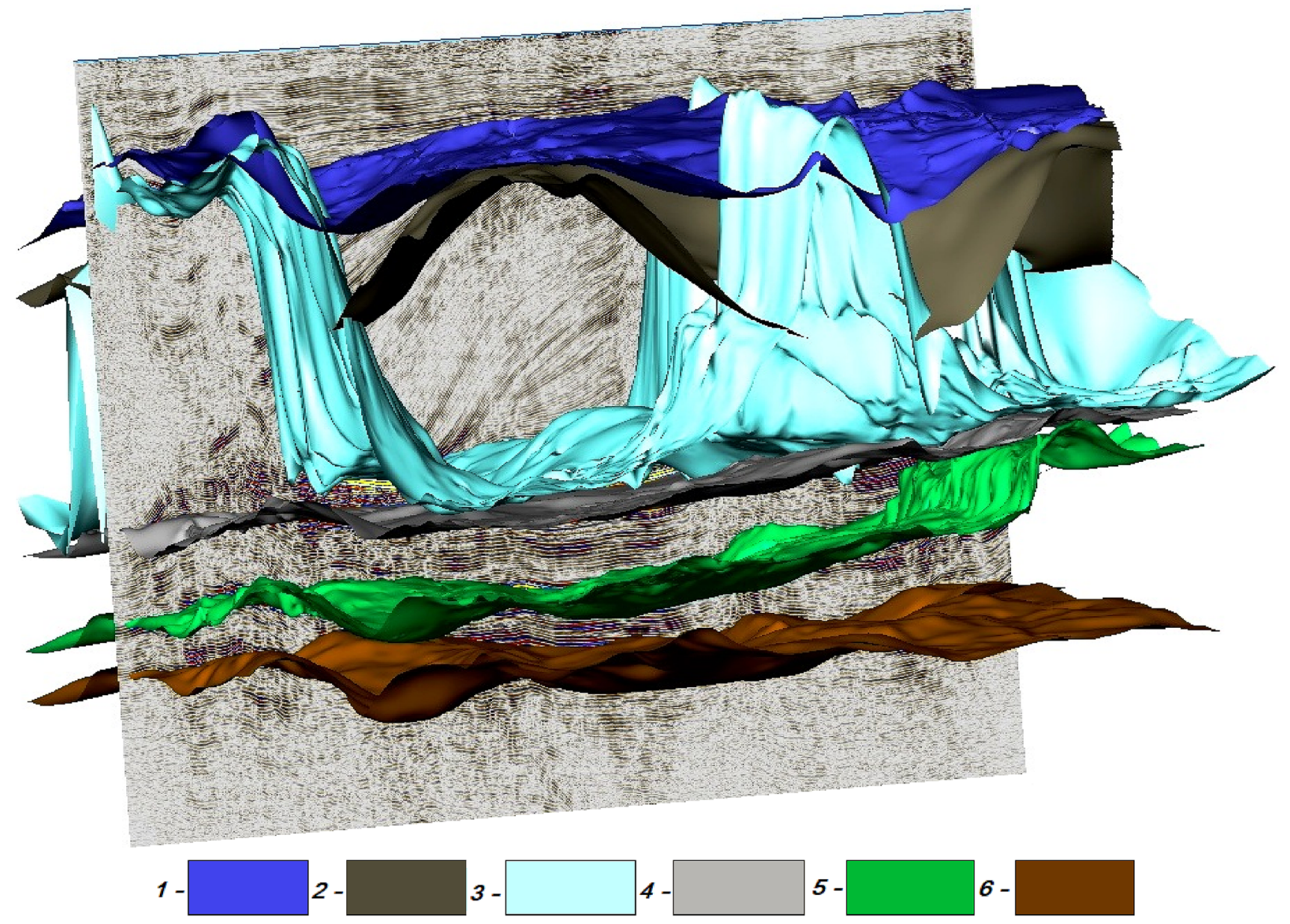

Fig. 4 Structural model demonstrating geological settings of the area. Seismic horizons: 1-dark blue-bottom Triassic (D); 2-dark greyPermian horizon (S); 3-light blue-top of Kungurian salt (VI); 4-light-grey—-top pre-salt formation, P1as +s+a (П1); 5-green- middle Carboniferous (П2); 6-brown-top devonian (П3) (area of location and horizons nomenclature please refer to Fig. 2 and second to the last column on Fig. 3) 


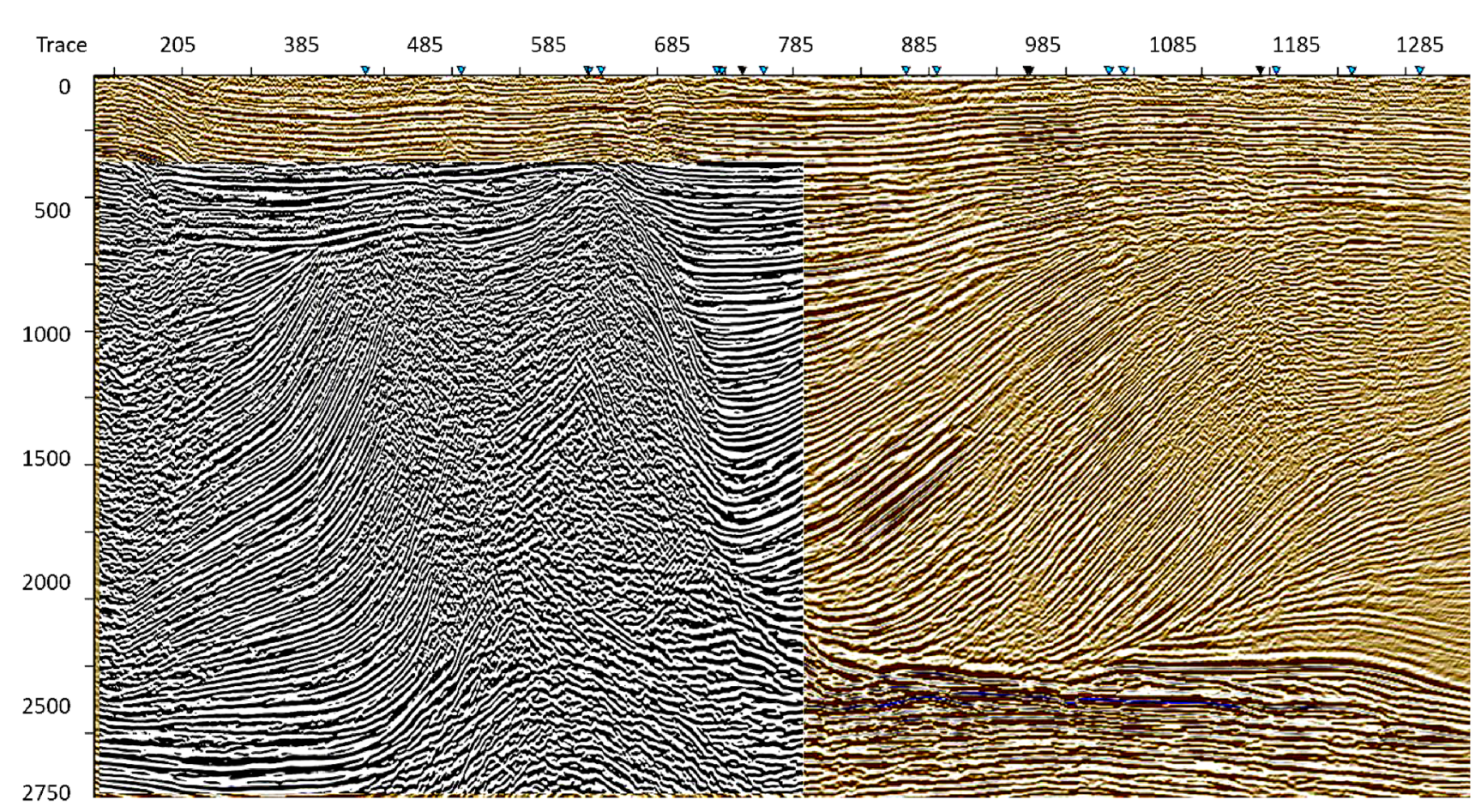

Fig. 5 Overhang trapped structure identified by 2D seismic pinpointed by cosine phase seismic attribute

et al. 2019). It could be trapped by walls of salt domes or by salt overhang commonly. The modern seismic technology improves the ability to map the structure of post-salt sequences in depressions between salt domes, resulting in new types of structures such as subtle anticline in depressions against slopes of salt domes. These structures are recognized mainly in Upper Permian rocks.

Formation of the traps is related to the halo-kinematics of non-uniform withdrawal of salt into adjacent domes during emplacement. As classified by "Heavy oil Science centre", types of traps identified in the region created in different rock layers, and thus certain oil traps predominate in rocks of each age, examples of which sown on the Fig. 6.

- When underlying beds were tilted, eroded, and then covered with flat-lying impermeable rocks, then oil and gas may be trapped at the unconformity, which a break in the depositional sequence of rocks, thus this type of traps are very important sources of petroleum;

- Anticline structure formed when rock layers are pushed up by salt diapir as shown on Fig. $6 \mathrm{~b}$ after deposition. Gas and oil may be trapped at the top of the arch in reservoir rock if a cap of impermeable rock lies above. Structural trap may form also due to sideways pressures, or because of partial collapse and shifting of deeply buried salt beds. This types of trap are major sources of petroleum;
- Pinchout traps are common in an post-salt section of studied area, they forming when reservoir rock ends suddenly, leaving only impermeable rock;

- Up-dip plug between salt domes block the upward flow of petroleum. This trap type can also form when impermeable shales are deposited in channels through a lower reservoir layer, forming a barrier or dam.

Generally, the Lower Permian Kungurian sequence is the principal regional seal for pre-salt reservoirs of the Pre-Caspian basin and it covers the entire basin area except for local salt windows where salt either was pressed out or where salt was truncated during pre-Jurassic orogeny.

Kungurian salt is deformed into numerous domes alternating with depressions, in which the deposits are thin or absent due to lateral flowage. Where the otherwise impermeable seal is absent, hydrocarbons were afforded avenues to migrate from pre-salt source rocks vertically into post-salt reservoirs like as Lower Triassic sandstones.

The salt formation divides the sedimentary succession into two well defined hydrodynamic systems. Ubiquitous overpressure and significantly higher salinity of formation water characterize the pre-salt system, whereas pressure is hydrostatic and salt content in formational water is lower in the post-salt system.

Various local and semi-regional shale seals that directly overlie hydrocarbon pools in pre-salt reservoirs probably

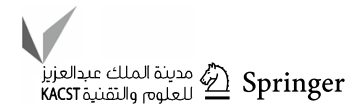



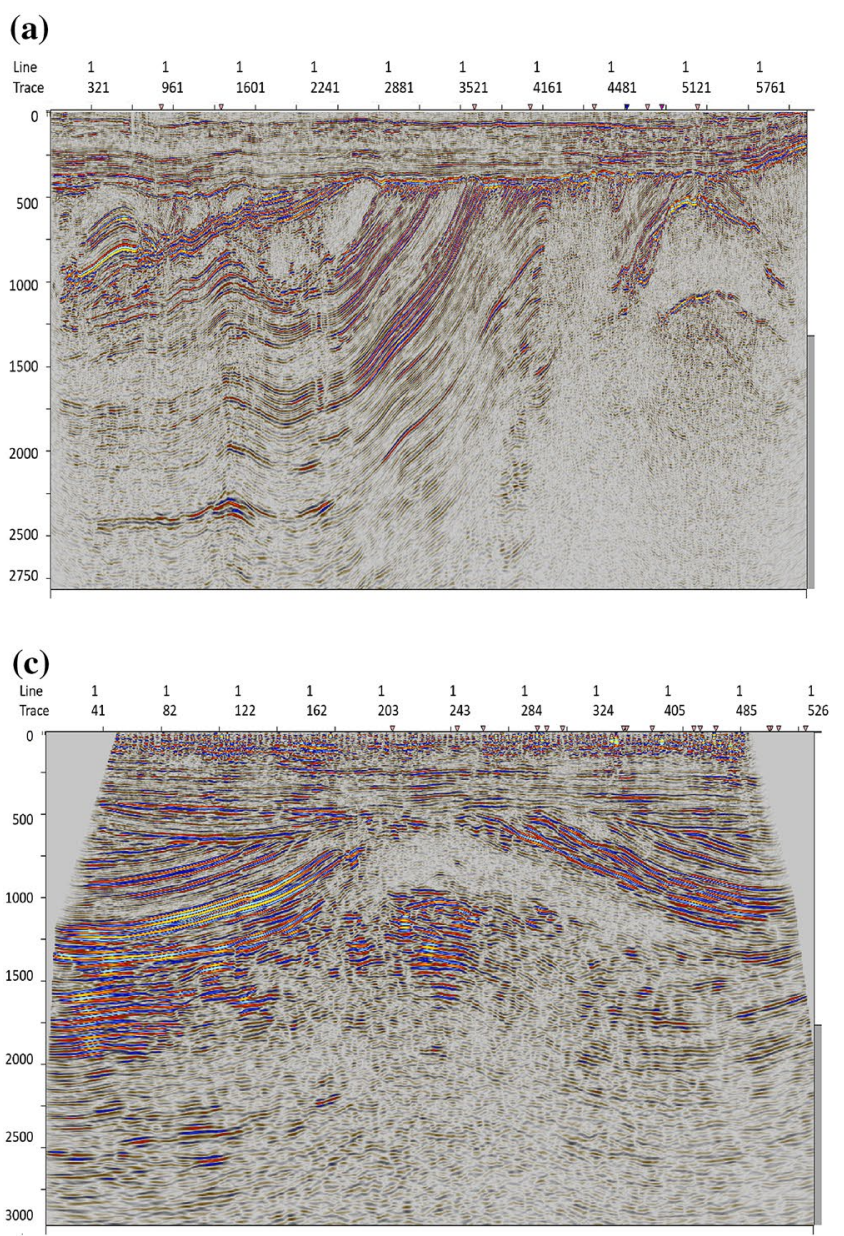
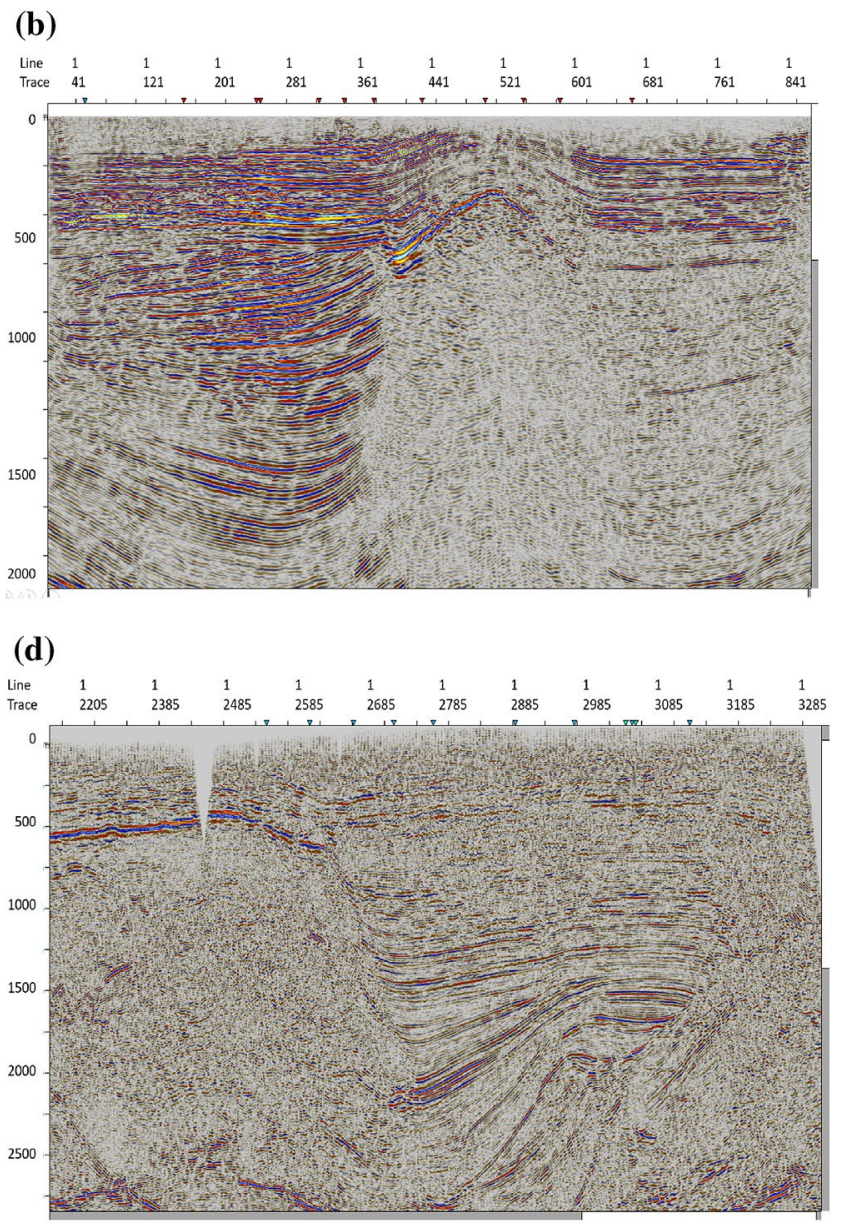

Fig. 6 Trap types: a unconformity; $\mathbf{b}$ anticline or dome; $\mathbf{c}$ pinchout; $\mathbf{d}$ up-dip plug

would be effective. Triassic, Upper Jurassic and Cretaceous marine shale beds seal hydrocarbon pools in post-salt rocks.

\section{Conclusions}

No qualified source rocks have been penetrated to date within area under the study. However, it is possible to predict a presence of source rock in this part of depression, which is evidenced by deep wells from other part of PreCaspian Basin. It also could be migrated from deeper part of basin following salt windows or fault, which is connecting between pre- and post-salts clastics.

Identified prospects are mainly salt-related faulted structures, bounded by normal faults and structural up-dip portion of the prospect. This kind of trapping mechanism has a risk of leakage through faults. However, based on results of drilling of old wells, it is proved that faults act as a sealentrapping hydrocarbon through geologic time period.

The reservoir for post-salt system is composed of a couple of pairs of shallow marine and terrestrial clastics of upper
Permian and Triassic age. Sandstones interbedded with siltstones and shale, which is correlated from neighboring fields, has a good quality of reservoir characteristics.

Designed exploratory well proposed to test anticline closure adjoining to the salt body is a vertical well aimed to test Upper Permian and Triassic suites with total depth of $800 \mathrm{~m}$. Based on analysis of drilled earlier wells no significant shallow gas events were expected at the drilling location.

Open Access This article is licensed under a Creative Commons Attribution 4.0 International License, which permits use, sharing, adaptation, distribution and reproduction in any medium or format, as long as you give appropriate credit to the original author(s) and the source, provide a link to the Creative Commons licence, and indicate if changes were made. The images or other third party material in this article are included in the article's Creative Commons licence, unless indicated otherwise in a credit line to the material. If material is not included in the article's Creative Commons licence and your intended use is not permitted by statutory regulation or exceeds the permitted use, you will need to obtain permission directly from the copyright holder. To view a copy of this licence, visit http://creativecommons.org/licenses/by/4.0/. 


\section{References}

Abilkhasimov KhB (2016) Specific features of formation of paleozoic reservoirs of the pre-caspian sedimentary basin and evaluation oil and gas bearing potential. Monography. Moscow. Publishing House of the Academy of Natural Sciences Academy. https:// monographies.ru/ru/book/section?id $=11860$

Akhmetzhanov A, Abdelmaksoud AS, Muratova S, Shukmanova A, Muzapparova A (2017) Hydracorbon plays and oil bearing potential of Eastern margin of the Pre-Caspian Sedimentary Basin. In: 17-th international multidisciplinary scientific geoconference SGEM 2017. www.sgem.org, SGEM2017 conference proceedings, ISBN 978-619-7408-00-3/ISSN 1314-2704, 29 June-5 July, 2017, Vol. 17, Issue 14, 687-696 pp, https://doi.org/10.5593/ sgem2017/14/s06.086

Alsouki M, Taifour R, Al Hamad O (2014) Delineating the fluvial channel system in the Upper Triassic formation of the Elward area in the Syrian Euphrates Graben using 3-D seismic attributes. J Petrol Explor Prod Technol 4:123-132. https://doi.org/10.1007/ s13202-014-0110-5

Ameloko AA, Uhegbu GC, Bolujo E (2019) Evaluation of seismic and petrophysical parameters for hydrocarbon prospecting of G-field, Niger Delta, Nigeria. J Petrol Explor Prod Technol 9:2531-2542. https://doi.org/10.1007/s13202-019-0735-5

Brunet M-F, Yu A, Volozh MP, Lobkovsky LI (1999) The geodynamic evolution of the Precaspian basin (Kazakhstan) along a northsouth section. Tectonophysics 313:85-106

Dalyan IB, Bulekbayev ZE (1993) Oil pools search in the post-salt deposits of the East Pre-Caspian. Oil and Gas Geology. No 1. UDK 556.3:626.862. (in Russian)

Davies O, Steve T (2012) New insights into hydrocarbon plays in the Caspian Sea, Kazakhstan. Pet Geosci 18:253

Hakiki and Shidqi (2018) Revisiting fracture gradient: comments on "A new approaching method to estimate fracture gradient by correcting Matthew-Kelly and Eaton's stress ratio". Petroleum 4(1):1-6. https://doi.org/10.1016/j.petlm.2017.07.001

Hanafy S, Nimmagadda SL, Mahmoud SE, Hemdan KH (2014) New Insights on interpretation of seismic attributes in the Nile Delta basin for analysing pliocene geological characteristics. In: MOC 2015, Cairo, Egypt

Hanafy S, Nimmagadda SL, Mahmoud SE et al (2017) New insights on structure and stratigraphic interpretation for assessing the hydrocarbon potentiality of the offshore Nile Delta basin, Egypt. J Petrol Explor Prod Technol 7:317-339. https://doi.org/10.1007/ s13202-016-0264-4

Herndon JM (2017) New concept on the origin of petroleum and natural gas deposits. J Petrol Explor Prod Technol 7:341-352. https:// doi.org/10.1007/s13202-016-0271-5

Jean-Pierre Barde, Peter Gralla, Josef Harwijanto, Juergen Marsky (2002) Exploration at the eastern edge of the precaspian basin: impact of data integration on upper permian and triassic prospectivety. AAPG Bull 86(3):399-415

Kamali MR, Abolghasemi A, Bagheri R et al (2013) Petroleum geochemistry and oil-oil correlation of the Fahliyan and Surmeh reservoirs in the Garangan and Chilingar oilfields, the Dezful embayment (Sw Iran). J Petrol Explor Prod Technol 3:85-92. https://doi. org/10.1007/s13202-012-0048-4

Katherine AG, Mark GR (2012) Concepts in halokinetic-sequence deformation and stratigraphy. Geol Soc Lond Spec Publ 363:7-31

Kirilov AS, Zakrevsky KE (2014) Practical course for petrel seismic interpretation. MAI-Print, Moscow (in Russian). ISBN 978-5-7035-2324-7

Klett TR, Schenk CJ, Charpentier RR et al (2010) Assessment of undiscovered oil and gas resources of the North Caspian Basin, Middle Caspian Basin, North Ustyurt Basin, and South Caspian Basin
Provinces, Caspian Sea Area, USGS Energy Program. http://energ y.cr.usgs.gov/oilgas/

KMG Annual Report (2017) https://kmg.kz/self/annual_report_2017/ download/KMG_2017_EN.pdf

Munyithya JM, Ehirim CN, Dagogo T et al (2020) Seismic amplitudes and spectral attribute analysis in reservoir characterisation, 'MUN' onshore Niger delta field. J Petrol Explor Prod Technol 10:2257-2267. https://doi.org/10.1007/s13202-020-00917-1

Osinowo OO, Ayorinde JO, Nwankwo CP et al (2018) Reservoir description and characterization of Eni field Offshore Niger Delta, southern Nigeria. J Petrol Explor Prod Technol 8:381-397. https ://doi.org/10.1007/s13202-017-0402-7

Quirk DG, Pilcher R (2005) Flip-flop salt tectonics. In: AAPG International conference and exhibition, Paris, 11-14 Sep

Santamarina et al. (2019) Soil properties: physics inspired, data driven. In: Lu N., Mitchell J. (eds) Geotechnical fundamentals for addressing new world challenges. Springer Series in Geomechanics and Geoengineering. Springer, Cham. https://doi. org/10.1007/978-3-030-06249-1_3

Santamarina JC, Garcia A, Park HF, Zhao B (2019) Multiphysics low-perturbation methods for sediment characterization and process monitoring. In: Fifth international conference on engineering geophysics, Al Ain, UAE, 21-24 October 2019. https://doi. org/10.1190/iceg2019-042.1

Soloviev BD (1992) The evolution stages and oil and gas potential of sedimentary cover of the Pre-Caspian depression. Oil Gas Geol. No. 8, (in Russian)

Ulmishek GF (2001) Petroleum geology and resources of the North Caspian Basin, Kazakhstan and Russia. U.S. Geological Survey Bulletin 2201-B. Version 1.0. https://pubs.usgs.gov/bul/2201/B/ b2201-b.pdf

Velaj T (2015) The structural style and hydrocarbon exploration of the subthrust in the Berati Anticlinal Belt, Albania. J Petrol Explor Prod Technol 5:123-145. https://doi.org/10.1007/s1320 2-015-0162-1

Volozh Y, Talbot C, Ismail-Zadeh A (2003) Salt structures and hydrocarbons in the Pricaspian basin. AAPG Bull 87(2): 313-334. https://www.academia.edu/2905149/Salt_structures and_hydrocarbons_in_the_Pricaspian_basin

Heavy oil Science centre. http://www.lloydminsterheavyoil.com/trapt ypes.htm

Zhenyun W, Hongwei Y, Xin W, Bo Z, Junzhang Z, Xingyuan W, Wei W (2015) The structural styles and formation mechanism of salt structures in the Southern Precaspian Basin: insights from seismic data and analog modeling. Marine Pet Geol 62:58-76. https://doi. org/10.1016/j.marpetgeo.2015.01.010

Zholtaev GZh, Talaev ZhU (1974) The history of development of Kenkiyak Salt dome (Eastern Margin of the Pre-Caspian tectonic depression) - In book "Oil and Gas". Alma-Ata, Kazakhstan. Issue 2:24-25

Zholtayev GZh, Akhmetzhanova G, Abuyev RB, Akhmetzhanov A, Oraz BB (2019) Geological features of triassic sediments of the eastern edge of the pre-caspian sedimentary basin. EAGE, Geomodel. September 9-13.2019. Gelendzhik, Russia. https://doi. org/10.3997/2214-4609.201950006

Publisher's Note Springer Nature remains neutral with regard to jurisdictional claims in published maps and institutional affiliations. 